\title{
Primary malignant fibrous histiocytoma of long bones: long-term follow-up
}

\author{
Uzun kemiklerin primer malign fibröz histiyositoması: Uzun süreli izlem
}

\author{
Bülent Özkurt, MD., ${ }^{1}$ Kerem Başarır, MD., ${ }^{2}$ Yusuf H. Yıldız, MD., ${ }^{2}$ \\ Mahmut Kalem, MD., ${ }^{2}$ Yener Sağlık, MD. ${ }^{2}$ \\ 1'Department of Orthopedics and Traumatology, Ankara Numune Training and Research Hospital, Ankara, Turkey \\ ${ }^{2}$ Department of Orthopedics, Oncology Section, Ankara University, School of Medicine, İbn-i Sina Hospital, Ankara, Turkey
}

\begin{abstract}
Objectives: This study aims to evaluate patients diagnosed with malignant fibrous histiocytoma and investigate the possible prognostic factors associated with duration of survival.

Patients and methods: The study, which was conducted between May 1994 and September 2013, included 14 patients diagnosed as malignant fibrous histiocytoma (12 males, 2 females; median age 48 years; range 17 to 64 years). We evaluated patients' demographic features, location of the pathology, histological findings, surgical margins, and treatment modalities and investigated the effects of these parameters on survival.
\end{abstract}

Results: Femur was the most frequently involved bone, followed by tibia and humerus. The median follow-up duration of the patients was 129 months. We performed limb salvage surgeries in 13 patients and amputation in one patient. Surgical margins were marginal in three patients and postoperative radiotherapy was performed for local control of the disease. Although there was no local recurrence in these patients, distant metastasis developed in two patients, indicating the importance of surgical margin as a significant factor on survival. Five-year survival rate was $81.9 \%$ in patients with wide surgical margins and $33.3 \%$ in patients with marginal margins.

Conclusion: Surgical excision with wide margins and adjuvant chemotherapy provided adequate control of the disease and longer survival. The only prognostic factor statistically significantly associated with duration of survival was surgical margins. Neoadjuvant chemotherapy may be used when there is a suspicion of not obtaining adequately wide surgical margin perioperatively due to close association with neurovascular structures.

Keywords: Bone neoplasms; malignant fibrous histiocytoma; primary. öz

Amaç: $\mathrm{Bu}$ çalışmada malign fibröz histiyositoma tanılı hastalar değerlendirildi ve sağkalım süresi ile ilişkili muhtemel prognostik faktörler araştırıldı.

Hastalar ve yöntemler: Mayıs 1994 - Eylül 2013 tarihleri arasında yapılan çalışmaya malign fibröz histiyositoma tanılı 14 hasta (12 erkek, 2 kadın; ortanca 48 yıl; dağılım 17-64 yıl) dahil edildi. Hastaların demografik özellikleri, patolojinin yeri, histolojik bulgular, cerrahi sınırlar ve tedavi yöntemleri değerlendirildi ve bu parametrelerin sağkalım üzerindeki etkileri araştırıldı.

Bulgular: En sık tutulan kemik femur idi, bunu tibia ve humerus izledi. Hastaların takip süresi ortanca 129 ay idi. On üç hastada ekstremite koruyucu cerrahi ve bir hastada amputasyon uygulandı. Üç hastada cerrahi sınırlar marjinal idi ve hastalığın lokal kontrolü için ameliyat sonrası radyoterapi uygulandı. Bu hastalarda hiç lokal nüks olmasa da iki hastada uzak metastaz gelişti, bu da cerrahi sınırın sağkalım üzerinde etkili önemli bir faktör olduğunu ortaya çıkardı. Beş yıllık sağkalım oranı geniş cerrahi sınırları olan hastalarda \%81.9, marjinal sinırları olan hastalarda $\% 33.3$ idi.

Sonuç: Geniş sınırlarla cerrahi eksizyon ve adjuvan kemoterapi yeterli hastalık kontrolü ve daha uzun sağkalım sağladı. Sağkalım süresi ile istatistiksel olarak anlamlı şekilde ilişkili tek prognostik faktör cerrahi sınırlar idi. Damar ve sinir yapılarıyla yakın ilişki nedeniyle cerrahi sırasında yeterli geniş cerrahi sınır elde edilememe şüphesi olduğunda, neoadjuvan kemoterapi kullanılabilir.

Anahtar sözcükler: Kemik neoplazileri; malign fibröz histiyositoma; primer.

- Received: January 12, 2016 Accepted: March 24, 2016

- Correspondence: Bülent Özkurt, MD. Ankara Numune Eğitim ve Araștırma Hastanesi Ortopedi ve Travmatoloji Kliniği, 06100 Altındağ, Ankara, Turkey. Tel: +90 312 - 3101111 Fax: +90 312 - 3103460 e-mail: drbulentozkurt@yahoo.com 
Malignant fibrous histiocytoma in somatic soft tissue has been reported in many cases, while descriptions of its bony counterpart are relatively rare. In about $75 \%$ of cases, malignant fibrous histiocytoma of bone (MFH-B) arises in the long bones of the appendicular skeleton. ${ }^{[1-6]}$

For the treatment of MFH-B, local treatment measures alone such as surgery and/or radiotherapy are not sufficient; the majority of patients develop metastases within two years and die of disseminated disease. Therefore MFH-B necessitates the use of combined local and systemic control of the disease with chemotherapy and surgery. ${ }^{[7]}$ This illness is known to include chemosensitive tumors and adjuvant or neoadjuvant chemotherapy as well as radiation therapy considerably improve outcomes. ${ }^{[7]}$

The aim of this study was to investigate the possible factors associated with increased survival rates. We also aimed to review our outcomes with particular attention to surgical margins and treatment plan.

\section{PATIENTS AND METHODS}

Fourteen patients were included in the study if they fulfilled the following criteria: histologically proven primary MFH-B, no prior history of cancer, primary admissions to our center and no prior history of pre-existing bone abnormalities, between May 1994 and September 2013. Six patients, who were suffering from MFH-B, could not be reached due to inadequate hospital file records or who refused to come to the final follow-up visit and one patient with secondary MFH-B following irradiation to the sacrum were not included the study. A total of 14 patients, (12 males, 2 females; median age 48 years; range 17 to 64 years) participated in the study. Demographic and clinical data including sex, age, complete medical history, physical examination and laboratory test results were obtained from patient files. The study protocol was approved by the ANEAH Local Ethics Committee. A written informed consent was obtained from each patient. The study was conducted in accordance with the principles of the Declaration of Helsinki.

In all cases preoperative diagnoses were confirmed with a fine needle aspiration combined with a core needle biopsy $(\mathrm{n}=10)$ or open biopsy $(n=4)$. Also in all cases postoperative pathological diagnosis was confirmed with histological analyses.

Surgical excision with wide margins was the intended treatment for all patients. Patients were classified according to the margins of the surgery performed. The necessity for radiotherapy was decided according to microscopic margin positivity and extension.

Adjuvant chemotherapy was used in all 14 patients. Adjuvant chemotherapy commenced three to four weeks after surgery in all patients. The chemotherapy regimen, with which the patients were treated, was intravenous high-dose methotrexate (range doses from $750 \mathrm{mg} / \mathrm{m}^{2}$ to $12 \mathrm{gram} / \mathrm{m}^{2}$, on day 21 , every cycle) in combination with doxorubicin or cisplatinum or ifosfamide. While doxorubicin $\left(60-75 \mathrm{mg} / \mathrm{m}^{2}\right.$ on day 1) and ifosfamide (1.8 gram $/ \mathrm{m}^{2}$ on day $1-5$ ) were given intravenously, cisplatinum $\left(120 \mathrm{mg} / \mathrm{m}^{2}\right.$ on day 1) was administered intra-arterially. Preoperative neoadjuvant chemotherapy was only given to one patient. This regimen consisted of methotrexate (intravenously, at the dose of $750 \mathrm{mg} / \mathrm{m}^{2}$ on day 1) and cisplatinum (intra-arterially at the dose of $120 \mathrm{mg} / \mathrm{m}^{2}$ on day 7) and doxorubicin (intravenously at the dose of $60 \mathrm{mg} / \mathrm{m}^{2}$ on day 9), every three weeks. After three cycles of chemotherapy, surgery was performed.

\section{Statistical analysis}

Data was analyzed using SPSS version 15.0 software (SPSS Inc., Chicago, IL, USA). Actuarial overall survival was calculated from the date of diagnosis until the date of the last follow-up appointment using the Kaplan-Meier method. Other potential prognostic factors, including gender, histological subtype and preoperative duration of the symptoms, were tested by Cox regression analysis.

\section{RESULTS}

There was a bimodal age distribution, with high incidences in people in their twenties and thirties ( 2 patients in each), and fifties $(n=7) .71 .4 \%$ of the patients were older than 40. All surviving patients continued to come to follow-up appointments for five years and the median follow-up period of all patients was 129 months (range 4-192 months). Two patients (patient 5 and 7) died of the disease: one with lung metastases and the other with liver and lung metastases, 25 months and 32 months after surgery respectively. A third patient (patient 4) died in a traffic accident, 18 months after surgery with no evidence of disease at the last follow up. A fourth patient (patient 2) was reported to have died at home four months after surgery because of an unknown reason. The remaining 10 cases were still alive and showed no evidence of disease at the last follow-up. The median follow-up period of the living patients was 143 months (range 111-192 months).

The long bones of the appendicular skeleton were the most commonly involved sites $(n=12)$. The femur 

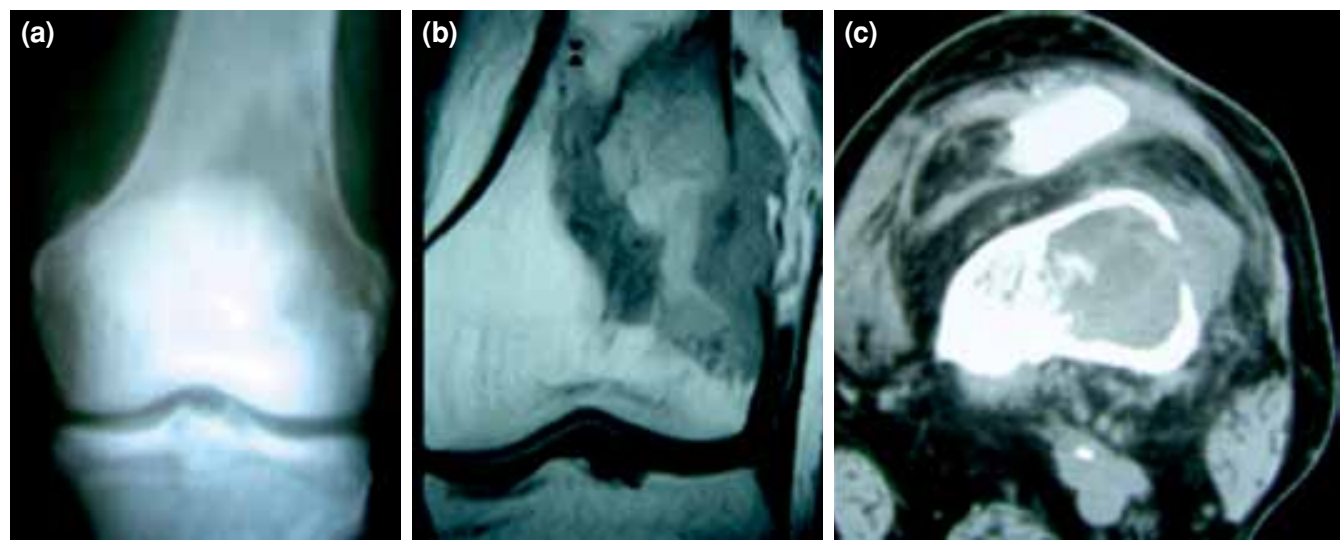

Figure 1. (a) Preoperative posteroanterior X-ray of a patient revealing an eccentrically located, destructive lesion on the distal metaphysis of left femur. (b) Preoperative magnetic resonance imaging of the patient demonstrating an eccentrically located lesion with soft tissue mass. (c) Preoperative computed tomography scan of the patient which showed an eccentrically located destructive lesion with adjacent soft tissue involvement.

was the most commonly affected bone $(n=8)$. In two patients, the proximal tibial region, in one patient ilium, in one case distal radial region, in one case tarsal bone, and in one case the humerus was affected. There were no cases with multi-centric disease.

The surgical margins were wide in 11 of the cases $(78.6 \%)$ and marginal in three of the cases $(21.4 \%)$. In the two cases with limb salvage surgery, surgical margins were judged adequate and tumorcell negative. In the amputation patient, reamputation was offered and the patient refused to undergo a further surgery. Radiotherapy was administered postoperatively to the three patients with marginal surgical margins.

During the histological evaluation, all the patients were morphologically high grade. According to the French Fédération Nationale des Centres de Lutte Contre le Cancer (FNCLCC) grading system and a histopathological examination of all the cases in the study were G3.

Thirteen of the 14 patients had limb salvage procedures and one underwent amputation. In the patients who underwent limb salvage procedures;
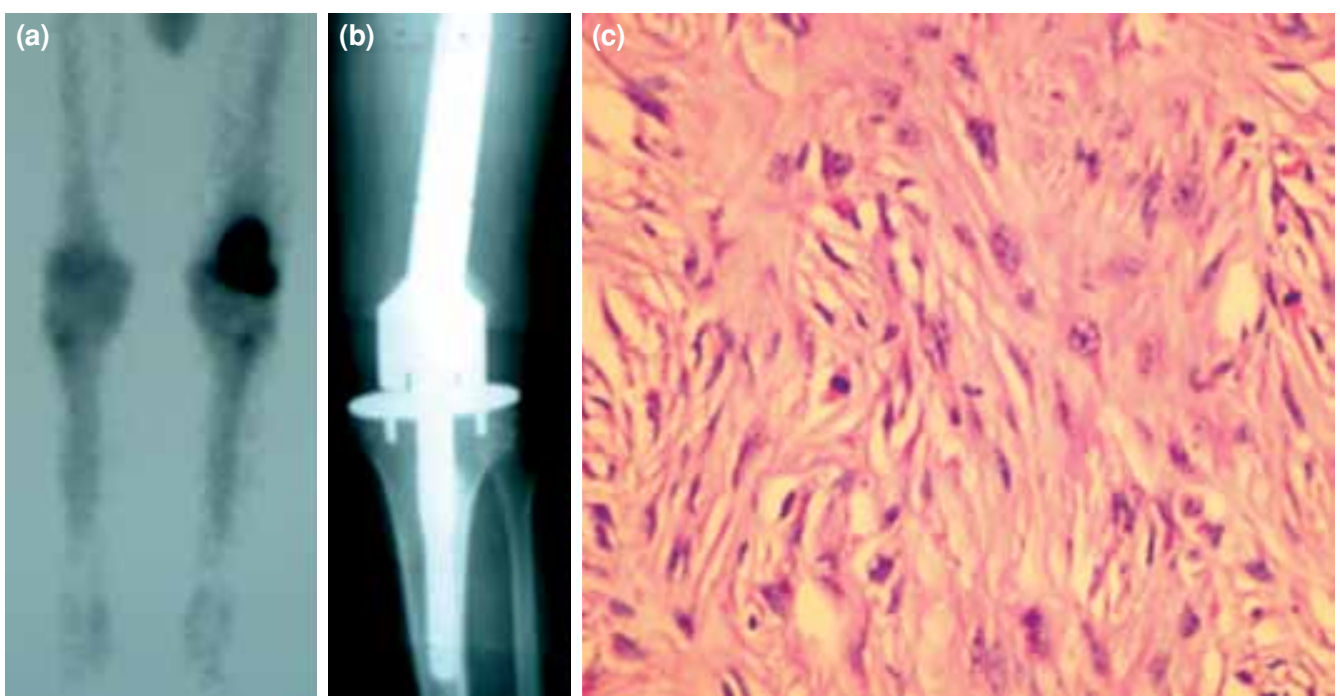

Figure 2. (a) Preoperative whole body scintigraphy revealing a lesion with increased osteoblastic activity on the distal metaphysis of left femur. Metastasis could not be detected. (b) Postoperative X-rays of the patient. The reconstruction was achieved with prosthesis. (c) 40x original magnification/hematoxylineosin-stain preparation revealing mitotically active pleomorphic sarcoma, phagocytosis, giant cells and collagen deposits. 


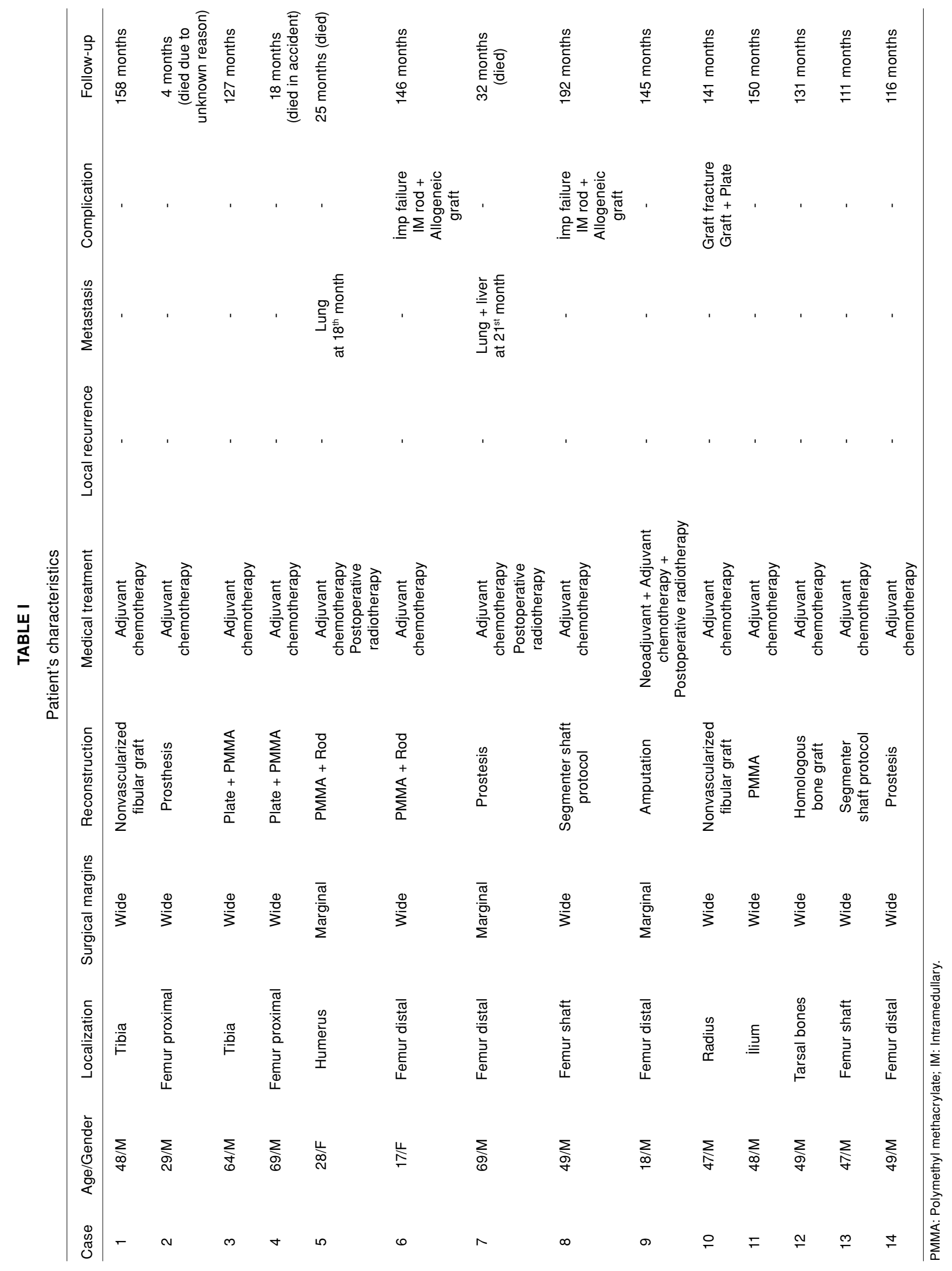


reconstructions were achieved using different techniques (Figures 1,2). The characteristics of the patients are shown in Table I.

Adjuvant chemotherapy was given to all 14 patients. Only one patient, who underwent amputation, also had neoadjuvant chemotherapy. In this case there was insufficient response to preoperative chemotherapy with less than $90 \%$ (nearly $70 \%$ ) tumor necrosis.

There were not any recurrences but two distant metastasis (one pulmonary and one pulmonary + hepatic metastases) observed in the study group. Both patients underwent marginal excision and postoperative radiotherapy and developed metastasis within two years of surgery. The two patients with metastases were in the marginal group with respect to surgery.

The Kaplan-Meier survival curve for the entire group included 95\% confidence limits at two and five years (Figure 3). Two- and five-year survival probabilities were $85.7 \%$ and $71.4 \%$, respectively. Surgical margins were a significant factor affecting survival. Patients with wide surgical margins had a five-year survival probability of $81.9 \%$ (9 of 11 patients), compared with $33.3 \%$ (1 of 3 patients) for patients with marginal surgical margins, and this difference was statistically significant $(p<0.05)$.

Other potential prognostic factors, including age, gender and histological subtype were evaluated by cox regression analysis, but were not significantly related to survival $(p>0.05)$. The risks for relapse between limb salvage and amputation and the relationship

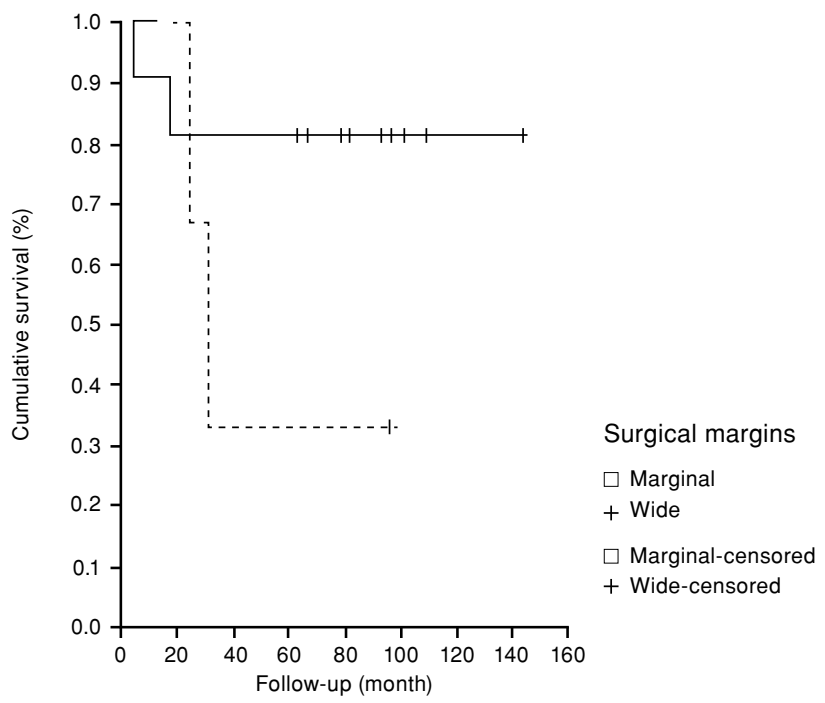

Figure 3. Kaplan-Meier Survival Analysis of 14 patients with malignant fibrous histiocytoma of bone revealed a five year survival of $71.4 \%$. between the site of the lesion and survival could not be evaluated statistically due to the inadequate number of patient.

\section{DISCUSSION}

Although MFH-B occurs primarily as a tumor in the majority of cases, it may also occur secondarily in preexisting bone lesions in up to $25 \%$ of cases. ${ }^{[1,8-10]}$ Our 14 patients accounted for $2.2 \%$ of primary malignant bone tumors in our clinic. There was only one case of secondary MFH-B after irradiation, and this patient was excluded from the study.

Bone tumors may exhibit variable biological behavior. ${ }^{[11]}$ Prognosis depends on local recurrence and metastases. A review of the literature reveals different rates of metastases and local recurrences between $30-70 \% .{ }^{[5,12]}$ Several authors emphasize that preoperative and/or adjuvant chemotherapy reduces the ever present threat of microscopic residual local or metastatic disease. ${ }^{[3-5,8,10,12]}$ In the present study, the lower rate of metastasis (14\%), when compared with reports of the cases who underwent only surgery and/or radiotherapy, supports the effectiveness of chemotherapy in MFH-B.

The mainstay treatment for MFH-B is wide resection with adjuvant chemotherapy. ${ }^{[3,9,13,14]}$ Intralesional or marginal excision is associated with a high local recurrence rate and metastasis. ${ }^{[9]}$ Although adjuvant chemotherapy has been shown to improve the survival rate and reduce the incidence of metastasis, ${ }^{[9]}$ chemotherapy alone is not successful without adequate resection. ${ }^{[9]}$ In two patients in our study group who had marginal surgical margins, pulmonary and liver metastases developed 18 and 21 months after surgery. None of the patients with wide surgical margins had a known metastasis.

Although several investigators have employed preoperative radiotherapy with varying degrees of success ${ }^{[6]}$ local recurrence and/or distant metastases have been reported in approximately one-half to two-thirds of patients who underwent local therapies within five years. ${ }^{[12]}$ Postoperative radiation therapy has been recommended for patients with marginal surgical margins in postoperative histological evaluation. ${ }^{[13,15,16]}$ In our series, radiotherapy was administered to three patients with marginal surgical margins. Reports of the outcome of the patients who received loco-regional treatment as surgery alone and/or radiation therapy were disappointing, and adjuvant chemotherapy was introduced with encouraging results. ${ }^{[3,7,13]}$ In the present study, patients with wide surgical margins had a five-year survival rate of $81.9 \%$, compared with $33.3 \%$ for patients with 
marginal surgical margins. High survival rates in our study suggest that wide resection is the mainstay of treatment and adjuvant chemotherapy is beneficial in MFH-B.

Neoadjuvant chemotherapy has been employed with varying degrees of success. ${ }^{[4,5,7,12]}$ Picci et al. ${ }^{[12]}$ reported that one-fourth and one-third, respectively, of MFH-B patients had good histological response to preoperative treatment, and suggested that in MFH-B immediate surgery followed by adjuvant chemotherapy would be more beneficial. ${ }^{[7]}$ In our series, only one patient received neoadjuvant chemotherapy with partial response.

In conclusion, our study suggests that wide resection is the mainstay of treatment, adjuvant chemotherapy is beneficial in MFH-B and obtaining an adequate surgical margin is the most important factor affecting the prognosis for survival and relapse in MFH-B. Malignant fibrous histiocytoma of bone is an aggressive tumor with the potential for both local recurrence and metastatic spread. Therefore, it is appropriate to administer chemotherapy in addition to radical resection or wide excision of the lesion, in order to improve survival rates from this disease.

\section{Declaration of conflicting interests}

The authors declared no conflicts of interest with respect to the authorship and/or publication of this article.

\section{Funding}

The authors received no financial support for the research and/or authorship of this article.

\section{REFERENCES}

1. Romeo S, Bovée JV, Kroon HM, Tirabosco R, Natali C, Zanatta L, et al. Malignant fibrous histiocytoma and fibrosarcoma of bone: a re-assessment in the light of currently employed morphological, immunohistochemical and molecular approaches. Virchows Arch 2012;461:561-70.

2. Akpinar A, Ozdemir CO, Ucler N, Inan HM. Storiformpleomorphic type of multifocal malignant fibrous histiocytoma of the lumbar spine. Am J Case Rep 2014;15:565-8.

3. Teng H, Xinghai Y, Wei H, Huang Q, Xiao J, Zhang C. Malignant fibrous histiocytoma of the spine: a series of 13 clinical case reports and review of 17 published cases. Spine (Phila Pa 1976) 2011;36:1453-62.
4. Bramwell VH, Steward WP, Nooij M, Whelan J, Craft AW, Grimer RJ, et al. Neoadjuvant chemotherapy with doxorubicin and cisplatin in malignant fibrous histiocytoma of bone: A European Osteosarcoma Intergroup study. J Clin Oncol 1999;17:3260-9.

5. Bacci G, Avella M, Picci P, Dallari D, Malaguti C, Biagini $\mathrm{R}$, et al. Primary chemotherapy and delayed surgery for malignant fibrous histiocytoma of bone in the extremity. Tumori 1990;76:537-42.

6. Kumar RV, Mukherjee G, Bhargava MK. Malignant fibrous histiocytoma of bone. J Surg Oncol 1990;44:166-70.

7. Bielack SS, Schroeders A, Fuchs N, Bacci G, Bauer HC, Mapeli S, et al. Malignant fibrous histiocytoma of bone: a retrospective EMSOS study of 125 cases. European Musculo-Skeletal Oncology Society. Acta Orthop Scand 1999;70:353-60.

8. Joo M, Lee GJ, Koh YC, Kwon OK, Park YK. Primary intraosseous malignant fibrous histiocytoma of the skull: a case report. J Korean Med Sci 2003;18:609-13.

9. Jebson PJ, Sullivan L, Murray PM, Athanasian EA. Malignant fibrous histiocytoma of the distal radius: a case report. J Hand Surg Am 2004;29:194-200.

10. Foti C, Giannelli G, Berloco A, Mascolo V, Ingravallo G, Giardina C. Malignant fibrous histiocytoma arising on chronic osteomyelitis. J Eur Acad Dermatol Venereol 2002;16:390-2.

11. Atik OŞ, Ayanoğlu T, Atalar H, Yörübulut M. One patient, one bone, and two different tumoral lesions. Eklem Hastalik Cerrahisi 2016;27:51-3.

12. Picci P, Bacci G, Ferrari S, Mercuri M. Neoadjuvant chemotherapy in malignant fibrous histiocytoma of bone and in osteosarcoma located in the extremities: analogies and differences between the two tumors. Ann Oncol 1997;8:1107-15.

13. Lehnhardt $\mathrm{M}$, Daigeler A, Homann $\mathrm{HH}$, Schwaiberger V, Goertz O, Kuhnen C, et al. MFH revisited: outcome after surgical treatment of undifferentiated pleomorphic or not otherwise specified (NOS) sarcomas of the extremities -- an analysis of 140 patients. Langenbecks Arch Surg 2009;394:313-20.

14. Iwata S, Yonemoto T, Araki A, Ikebe D, Kamoda H, Hagiwara $\mathrm{Y}$, et al. Impact of infiltrative growth on the outcome of patients with undifferentiated pleomorphic sarcoma and myxofibrosarcoma. J Surg Oncol 2014;110:707-11.

15. Kurywchak P, Kiefer J, Lenkiewicz E, Evers L, Holley $\mathrm{T}$, Barrett $\mathrm{M}$, et al. Elucidating potentially significant genomic regions involved in the initiation and progression of undifferentiated pleomorphic sarcoma. Rare Tumors 2013;5:14.

16. Vasileios KA, Eward WC, Brigman BE. Surgical treatment and prognosis in patients with high-grade soft tissue malignant fibrous histiocytoma of the extremities. Arch Orthop Trauma Surg 2012;132:955-61. 